\title{
Profile of users receiving Speech-Language Therapy service at a Critical Patient Unit
}

Universidad Santo Tomás, Facultad de Salud, Escuela de Fonoaudiología, Viña del Mar, Valparaíso, Chile.

Conflict of interests: Nonexistent

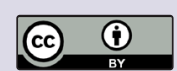

Received on: February 17, 2020

Accepted on: September 24, 2020

Corresponding address:

Manuel del Campo Rivas

Escuela de Fonoaudiología

Avenida Uno norte $3041,5^{\circ}$ piso

Código Postal: 2561694 - Viña del Mar,

Valparaíso, Chile

E-mail:mdelcampo2@santotomas.cl
Manuel del Campo Rivas ${ }^{1}$ https://orcid.org/0000-0001-6076-2734

Pamela Estay Jorquera ${ }^{1}$ https://orcid.org/0000-0002-4635-5910

Gabriela Valencia Rojas ${ }^{1}$ https://orcid.org/0000-0003-4190-7971

Paula Muñoz Ramos ${ }^{1}$ https://orcid.org/0000-0002-2795-9532

Karen Arce Rossel ${ }^{1}$ https://orcid.org/0000-0003-2906-5118

Angélica Silva-Ríos ${ }^{1}$ https://orcid.org/0000-0002-2116-1087

\section{ABSTRACT}

Objective: to describe the profile of patients treated by Speech-Language therapists in a Critical Patient Unit.

Methods: an ex post facto, observational and descriptive study was carried out. Monthly statistical data of patients hospitalized in the period January-December 2018 were analyzed, in the Intensive Care Unit at a public hospital. Data were described from the analysis of frequency and measures of central tendency. The distribution of the variables was determined through the skewness-kurtosis test, considering a significance level of $p<0.05$.

Results: 217 individuals got 868 speech-language therapy services. Men (57.26\%), older than 65 years old, required a more frequent intervention. The main medical diagnosis of admission to the unit corresponded to non-specific pathologies (57.14\%), respiratory disease (15.21\%) and cerebrovascular disease (12.79\%). The speechlanguage therapy functions were related to the evaluation of swallowing (54.31\%) and voice (32.4\%). In relation to the intervention, the treatment of dysphagia (25.82\%) and oral motor functions $(25.04 \%)$ was predominant in the duties. Functions associated with language, speech and cognition were secondary.

Conclusion: the profile of the critical patient and the speech-language therapy work in this field represent a first step to characterize the role of the speech-language therapist in Intensive Medicine teams.

Keywords: Critical Care; Speech-Language Pathology; Professional Practice 


\section{INTRODUCTION}

Speech-Language Therapy, as a discipline focused in communication and human swallowing ${ }^{1}$, has recently been incorporated into the Chilean Society of Intensive Medicine, recognizing their work as part of the professional team in the care of critical patients ${ }^{2}$.

The Critical Patient Units (CPU) comprehend a clinical structure of low and medium stay, which include the Intensive Care Unit (ICU) and the Intermediate Care Unit (IMCU) ${ }^{3}$.

This hospital service has mainly medical and nursing professionals, for the advanced treatment and to support people in life risk ${ }^{4,5}$. Speech-language therapy has been incorporated in the swallowing therapy ${ }^{6-8}$, linguistic-communicative therapy $y^{9,10}$ and cognitive therapy ${ }^{11,12}$ of critical patients, developing a role specifically as a rehabilitator in this context ${ }^{13}$.

The critical patient has been defined as a physiologically unstable person who requires an advance life support ${ }^{14}$. The population admitted at the adult CPU is usually elderly and can present alterations in areas of relevance to speech-language therapy ${ }^{15}$.

Internationally, Speech-Language Therapy at CPU has been described and defined for pediatric ${ }^{16}$ and adult $^{13}$ population, considering the rehabilitation of swallowing as the most relevant responsibilities ${ }^{7,17}$ and the handling of tracheostomized patients ${ }^{18}$.

Even though the patients hospitalized at the CPU can receive an early intervention from the rehabilitators ${ }^{19}$, the effect of those interventions still seems to be heterogeneous ${ }^{20,21}$, which makes it necessary to develop some research in the area. In Colombia, for example, the speech-language therapy services ${ }^{22}$ are focused mainly to treat problems related to swallowing and communication disorders ${ }^{23}$; in Brazil, on the other hand, the literature refers to therapy focused more on the swallowing treatment ${ }^{24,25}$; and in Chile, the research in this area is still beginning ${ }^{26}$, which is why there is no literature describing neither the characteristics of patients nor the type of speech-language therapy in this area.

This research aimed to describe the profile of users treated by speech-language therapists in a Critical Patient Unit.

\section{METHODS}

This study was approved by the Scientific Ethics Committee belonging to the University Santo Tomás, in Chile, code 53.19, and was sponsored by the Direction of the Hospital San Martín, in Quillota, Valparaíso Region, Chile. A quantitative study of observational design, descriptive, and ex post facto was carried out. Monthly Statistical Data (MSD) from the CPU were analyzed, related to patients who received speechlanguage therapy service during the year 2018.

The sample consisted of all the people who received speech-language therapy during 2018 in the adult CPU in the Hospital San Martín, in Quillota, Valparaíso Region, Chile. Since it was a study of secondary sources, all the patients treated in the service and in the period mentioned earlier were included. As inclusion criteria, the following information associated to the process of treatment was considered: service, month of treatment, gender, age, diagnosis, type and area of treatment. The exclusion criterion was the lack of complete information in the MSD.

The clinical profile of patients was described through the characterization of: gender, age, medical diagnosis, frequency, time and area of the speechlanguage therapy service. The frequency analysis was applied in the case of categorical variables and measures of central tendency for continuous variables. Aiming to determine the distribution of the variables, the skewness-kurtosis test was used, considering a significance level of $p<0.05$. Software's were used, Microsoft Excel to tabulate data, and Stata 14, to analyze those data.

\section{RESULTS}

During 2018, the adult CPU in the Hospital San Martín, Quillota, performed 868 speech-language therapy services to 217 individuals, coming from varied clinical services and/or derived from other centers. The medical diagnosis of critical patients was organized into related groups for statistical purpose. From these data, a $99.77 \%$ could be validated, $57.26 \%$ of the patients treated being males, and $42.74 \%$ females. The people admitted at the adult CPU were between 16 and 89 years old, this variable is not following a normal distribution $(p<0.001)$, therefore the median of 53 years was used for its characterization, being the age group between 65 and 69 the one who received the more proportion of treatment (19.82\%) (Figure 1). 


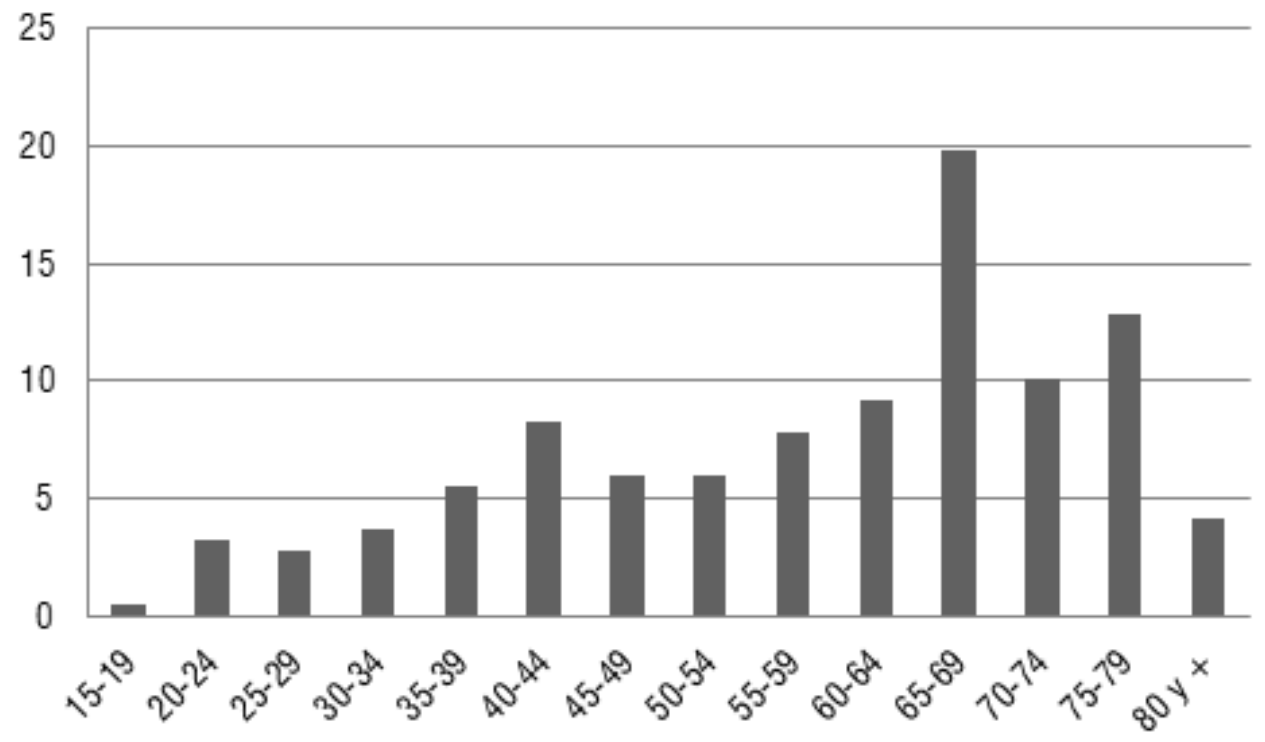

Figure 1. Proportion of patients treated, according to age

Likewise, the number of speech-language therapy services did not follow a normal distribution $(p<0.001)$, presenting a median of 71 therapy service per month, with a minimum of 48 , and a maximum of 96 . Added to that, each individual was visited four times by a speechlanguage therapist during his/her stay at the CPU. The time of these sessions was different, depending on the characteristics and needs of the treated patient, with a minimum of 30 minutes. The months of January, May, and October presented a higher frequency of therapies (Figure 2).

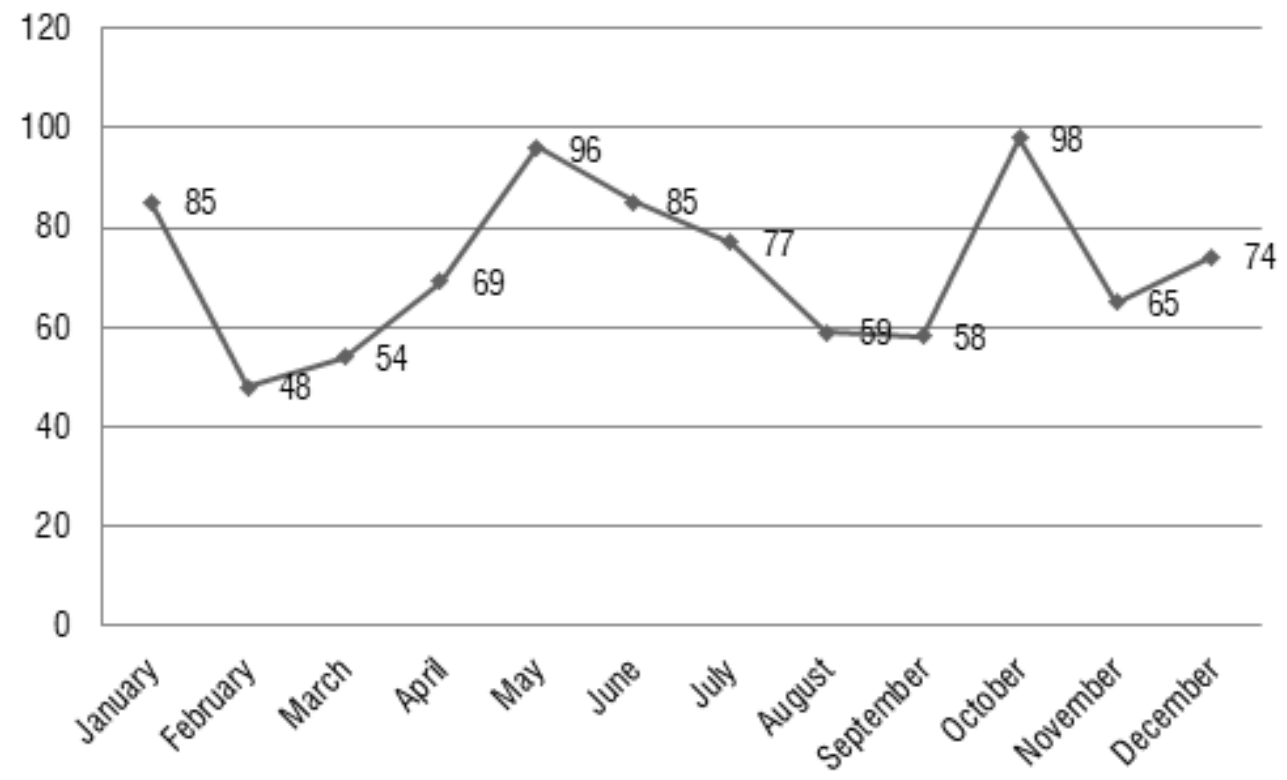

Figura 2. Frecuencia mensual de atención fonoaudiológica 
Regarding the type of MSD diagnosis, $57.14 \%$ of cases were considered as non-specified diagnosis (which were associated to abrupt infectious process or sepsis). On the other hand, $15.21 \%$ of the patients treated were admitted because of a respiratory pathology, followed by $12.79 \%$ of cerebrovascular accidents (Table 1).

Table 1. Type of diagnosis when admitted to the Critical Patient Unit

\begin{tabular}{lc}
\hline MSD* Diagnosis & $\%$ \\
\hline Non specified & 57.14 \\
Respiratory & 15.21 \\
Cerebrovascular disease & 12.79 \\
Cardiovascular & 7.37 \\
Chronical neuromuscular & 2.65 \\
Brain skull trauma & 2.53 \\
Acute neuromuscular & 1.38 \\
Trauma & 0.69 \\
Burn care & 0.23 \\
\hline
\end{tabular}

${ }^{*}$ MSD $=$ Monthly Statistical Data

Concerning the speech-language therapy assessment activities, $54.31 \%$ corresponded to functions linked to the swallowing area, with few therapy services related specifically to language or speech $(7 \%$ and $6 \%$, respectively) (Table 2). These activities are referred to actions of integral valorization of the patients who could present dysphagia, of mechanical, neurological and/or post-extubation origins. Additionally, they refer to the study of disorders which compromise the communication considering the base pathology and/or the comorbidities that triggered the aggravation of the subject.

Table 2. Speech-language therapy assessment functions

\begin{tabular}{lc}
\hline Assessment according to the area & $\%$ \\
\hline Swallowing & 54.31 \\
Voice & 32.4 \\
Language & 7.01 \\
Speech & 6.28 \\
\hline
\end{tabular}

From a therapeutic point of view, the swallowing treatment reached $25.81 \%$ of the speech-language therapy services, followed by $25.04 \%$ of rehabilitation of oral motor functions. In a lower proportion, appeared the language and/or cognitive stimulation intervention areas (Table 3).
Table 3. Speech-language therapy intervention functions

\begin{tabular}{lc}
\hline Treatment according to the area & $\%$ \\
\hline Swallowing & 25.82 \\
Oral motor functions & 25.04 \\
Phono articulatory organs & 24.22 \\
Voice & 17.26 \\
Family education & 3.14 \\
Speech & 2.04 \\
Language & 1.54 \\
Cognitive stimulation & 0.94 \\
\hline
\end{tabular}

\section{DISCUSSION}

The scope of speech-language therapy ${ }^{27}$ covers a broad spectrum of professional duties, from the promotion of heath, up to the rehabilitation of disorders which compromise the functionality of communication and swallowing ${ }^{1}$. Knowing the patient's profile from the perspective of speech-language therapy can contribute to the design and implementation of strategies adjusted to the characteristics of that population, which has an impact on the length of hospital stay ${ }^{13}$ and the costs associated to that treatment ${ }^{28}$. It is important to highlight that those actions should be framed within coordinated multidisciplinary teams which contribute transversally to the discharge of patients in vital risk ${ }^{29}$.

This research reveals a greater number of speechlanguage therapy services for people aged between 60 and 79 years old (Figure 1), which coincides with the Chilean epidemiological profile, where an increase of older population has been observed in the last decades ${ }^{30,31}$. Even though a high prevalence of non-specified MSD diagnosis was reported, it is possible to note that within this coding there are different types of sepsis, common diagnosis in the critical patient context ${ }^{32}$, reporting up to $48.1 \%$ of admission for this cause in another study ${ }^{33}$.

From a point of view of the duties of speechlanguage therapists, a concentration of actions in the areas of assessment and intervention in the swallowing field can be seen (table 2 and 3 ), which is coherent with what has been reported by international literature regarding the rehabilitation of dysphagia and the approach to the tracheostomized patients ${ }^{34}$. Aspects related to voice disorders appear as an area of relevance in this context (Table 2), probably due to the secondary laryngeal abnormalities to orotracheal intubation ${ }^{35,36}$, and/or the use of mechanical ventilation for long periods in the adult patient ${ }^{37}$, in consideration of the physiological modifications that these procedures 
could generate at a laryngeal level. It should be noted that even though the actions related to the approach to speech, language, and cognition are addressed in the $\mathrm{CPU}$, they are usually performed with more frequency in less complex units and/or at an outpatient level, since they require longer therapeutic periods of time, which can only happen once the patient has passed the critical phase of their illness.

One of the limitations of this research was related to narrowing down the data collection to only one hospital, due to logistical reasons. However, the data reported by this study offer a first approximation to the systematization of the patient's profile treated by speechlanguage therapists and the professional work in the field of intensive Medicine in Chile. As a perspective for future investigations, the need of assessing the effectiveness of the speech-language therapy, and performing analysis of effectivity cost in the CPU arises, as it is described in the international experience ${ }^{38-40}$, considering that speech-language therapy as a discipline in Chile, faces the challenge of validating and substantiating their work in this hospital setting. The clinical-epidemiological research, the economical assessment, and the controlled experimental studies will contribute to the achievement of this goal.

\section{CONCLUSION}

The profile of the critical patient who receive treatment at a unit for adults is that of an elderly patient, usually male and with a diagnosis associated to sepsis, respiratory and/or vascular pathologies. From the speech-language therapy practice, the professional who performs in the CPU, contributes to the comprehensive approach of people in vital risk, performing actions towards assessing and intervening in the swallowing process, the oral motor functions, and voice, and even acting with lower frequency in the speech, language and cognitive areas.

The characterization of the patient's profile and the professional duties of the speech-language therapist in the CPU of any complex hospital, offers a starting point for the future configuration of the role. Even though the specificity of the Intensive Medicine may tend to limit the professional act to swallowing rehabilitation, it is necessary to broaden the speech-language therapy task towards prevention and identification of other disorders in this context, to manage comprehensive care of people inside and outside the unit, in areas where professionals of communication and swallowing demonstrate their mastery.

\section{REFERENCES}

1. Vega YE, Rodríguez MA, del Campo MN. Análisis del rol del fonoaudiólogo(a) en el sector salud en Chile. Cienc Amp Trab. 2017;19(59):76-80.

2. SOCHIMI: Sociedad Chilena de Medicina Intensiva. La Sociedad Chilena de Medicina Intensiva incorpora nuevas disciplinas a su organización: fonoaudiología y terapia ocupacional [Internet]. 2018 [cited 2019 Jan 17]. Available at: https://www. medicina-intensiva.cl/

3. Huerta P, Igor J, Uribe S, Grandjean J, Burgos M. Movilización precoz en pacientes conscientes de la Unidad de Paciente Crítico Adultos del Hospital Regional de Valdivia. Valoración de la función cardiovascular, balance dinámico, calidad de vida $y$ el grado de independencia funcional al mes posalta. Rev Chil Med Intensiva. 2017;32(2):93-9.

4. Donovan AL, Aldrich JM, Gross AK, Barchas DM, Thornton KC, Schell-Chaple HM et al. Interprofessional care and teamwork in the ICU. Crit Care Med. 2018;46(6):980-90.

5. Kendall-Gallagher D, Reeves S, Alexanian JA, Kitto S. A nursing perspective of interprofessional work in critical care: findings from a secondary analysis. J Crit Care. 2017;38(1):20-6.

6. Baumgartner CA, Bewyer E, Bruner D. Management of communication and swallowing in Intensive Care: the role of the speech pathologist. AACN Adv Crit Care. 2008;19(4):433-43.

7. Macht M, Wimbish T, Clark BJ, Benson AB, Burnham EL, Williams $A$ et al. Diagnosis and treatment of post-extubation dysphagia: results from a national survey. J Crit Care. 2012;27(6):578-86.

8. Schefold JC, Berger $D$, Zürcher $P$, Lensch $M$, Perren A, Jakob SM et al. Dysphagia in mechanically ventilated ICU patients (DYnAMICS): a prospective observational trial. Crit Care Med. 2017;45(12):2061-9.

9. Happ MB, Baumann BM, Sawicki J, Tate JA, George EL, Barnato AE. SPEACS-2: Intensive Care Unit "communication rounds" with speech language pathology. Geriatr Nur. 2010;31(3):170-7.

10. Silva DLR e, Lira FOQ, Oliveira JCC de, Canuto MSB, Silva DLR, Lira FOQ et al. Speech therapy practice in the intensive care unit of a hospital of infectious diseases of Alagoas. Rev. CEFAC. 2016;18(1):174-83. 
11. Brummel NE, Jackson JC, Girard TD, Pandharipande PP, Schiro E, Work B et al. A Combined Early Cognitive and Physical Rehabilitation Program for people who are critically III: the activity and cognitive therapy in the Intensive Care Unit (ACT-ICU) trial. Phys Ther. 2012;92(12):1580-92.

12. Jackson J, Ely E, Morey M, Anderson V, Siebert C, Denne $L$ et al. Cognitive and physical rehabilitation of ICU survivors: results of the RETURN randomized, controlled pilot investigation. Crit Care Med. 2012;40(4):1088-97.

13. McRae J, Montgomery E, Garstang Z, Cleary $E$. The role of speech and language therapists in the intensive care unit. J Intensive Care Soc. 2019;0(0):1-5.

14. Lara BA, Cataldo A, Castro R, Aguilera PR, Ruiz C, Andresen M. Medicina de urgencia y unidades de cuidados intensivos: una alianza necesaria en busca de la mejoría de la atención de pacientes críticos. Rev Médica Chile. 2016;144(7):911-7.

15. Herrera E, Infante A. Guías 2004 de organización y funcionamiento de unidades de pacientes críticos. Rev Chil Med Intensiva. 2004;19(4):209-23.

16. ASHA: American Speech and Hearing Association. Roles and Responsibilities of Speech-Language Pathologists in the Neonatal Intensive Care Unit: Guidelines [Internet]. Rockville, MD: American Speech-Language-Hearing Association; 2005 [cited 2020 Jan 30]. Report No.: GL2005-00060. Available at: http://www.asha.org/policy/GL2005-00060/

17. de Medeiros GC, Sassi FC, Mangilli LD, Zilberstein $B$, de Andrade CRF. Clinical dysphagia risk predictors after prolonged orotracheal intubation. Clinics. 2014;69(1):8-14.

18. Rodrigues KA, Machado FR, Chiari BM, Rosseti $\mathrm{HB}$, Lorenzon P, Gonçalves MIR. Swallowing rehabilitation of dysphagic tracheostomized patients under mechanical ventilation in intensive care units: a feasibility study. Rev Bras Ter Intensiva. 2015;27(1):64-71.

19. Wilches E, López M, Arango G. Rehabilitación funcional del paciente neurológico en la UCI. Guía Neurológica 6 - La unidad de cuidado intensivo; 2004.

20. Sosnowski K, Lin F, Mitchell ML, White H. Early rehabilitation in the intensive care unit: an integrative literature review. Aust Crit Care Off J Confed Aust Crit Care Nurses. 2015;28(4):216-25.
21. Reid JC, Unger J, McCaskell D, Childerhose L, Zorko DJ, Kho ME. Physical rehabilitation interventions in the intensive care unit: a scoping review of 117 studies. J Intensive Care [Internet]. 2018 [cited 2020 Jan 27];6(80):1-12. Available from: https://www.ncbi.nlm.nih.gov/pmc/articles/ PMC6286501/

22. Marin YG, Nieto AP. Realidad laboral del fonoaudiólogo en la Unidad de Cuidados Intensivos. Rev signos fónicos. 2015;1(1):44-56.

23. Rodriguez Riaño J, Ballesteros Peréz DV, Franco Hernández SG, Burgos García M, Hernández Blanco ML, Ramírez Lozano MT. Práctica fonoaudiológica en unidades de cuidado crítico en Colombia [proyecto]. Corporación Universitaria Iberoamericana. [Internet]. 2018 [cited 2020 Feb 3]; Available from: http://repositorio.iberoamericana. edu.co/handle/001/842

24. Costa CC, Favero TC, Rosa FB da, Steidl EM dos S, Mancopes R. Decannulation: speech therapy and physiotherapy approach. Distúrb. Comun. 2016;28(1):93-101.

25. Padovani AR, Moraes DP, Sassi FC, Andrade CRF de. Clinical swallowing assessment in intensive care unit. CoDAS [Internet]. 2013 [cited 2020 Feb 3]; 25(1):1-7. Available from: http://www.scielo. br/scielo.php?script =sci_arttext $\&$ pid $=$ S2317$17822013000100002 \&$ Ing $=e n$.

26. Cartagena Goldschmidt T, Lillo Montecinos JA, Muñoz Diaz FJ. Rol del fonoaudiológico en unidad de paciente crítico, percepción del equipo multidiciplinario [Internet] [Thesis]. Universidad Andrés Bello; 2018 [cited 2020 Feb 3]. Available from: http://repositorio.unab.cl/xmlui/handle/ $\mathrm{ria} / 10213$

27. ASHA: American Speech and Hearing Association. Scope of Practice in Speech-Language Pathology [Internet]. American Speech-LanguageHearing Association. 2016 [cited Jun 2017 22]. Available from: http://www.asha.org/policy/ SP2016-00343/\#Framework

28. Neumeier A, Moss M. We need an additional seat at the critical care multidisciplinary team table for our speech-language pathologists. Ann Am Thorac Soc. $2014 ; 11(10): 1610-1$.

29. Cardinal L, Freeman-Sanderson A, Togher L. The speech pathology workforce in intensive care units: Results from a national survey. Aust Crit Care. 2020;33(3):250-8. 
30. Ganga Contreras F, Santana $P$, Angélica $M$, González Vásquez D, Rebagliati Badal F, Ganga Contreras F et al. Rol del Estado frente al envejecimiento de la población: el caso de Chile. Convergencia. 2016;23(71):175-200.

31. Villalobos Dintrans P. Panorama de la dependencia en Chile: avances y desafíos. Rev. méd. Chile [Internet]. 2019 [cited 2020 Sep 2]; 147(1):83-90. Available from: https://scielo.conicyt.cl/ scielo.php?script =sci_arttext\&pid=S003498872019000100083\&lng=es.

32. Ogura T, Nakamura Y, Takahashi K, Nishida K, Kobashi D, Matsui S. Treatment of patients with sepsis in a closed intensive care unit is associated with improved survival: a nationwide observational study in Japan. J Intensive Care [Internet]. 2018 [cited 2020 Feb 3]; 6(57)1-10. Available from: https://www.ncbi.nIm.nih.gov/pmc/articles/ PMC6122219/

33. Ochoa Parra M, Flores Enderica CG, Meneses Meneses MJ, Beltrán Zhindón MG, Arcentales Peralta MS, Bravo Genovéz AP et al. Prevalencia de infecciones en la Unidad de Cuidados Intensivos del Hospital José Carrasco Arteaga. Rev Médica Hosp José Carrasco Arteaga. 2016;8(2):137-41.

34. Skoretz SA, Riopelle SJ, Wellman L, Dawson C. Investigating swallowing and tracheostomy following critical illness: a scoping review. Crit Care Med. 2020;48(2):e141-51.

35. Brodsky MB, Levy MJ, Jedlanek E, Pandian V, Blackford B, Price $C$ et al. Laryngeal injury and upper airway symptoms after oral endotracheal intubation with mechanical ventilation during critical care: a systematic review. Crit Care Med. 2018;46(12):2010-7.

36. Jain U, McCunn M, Smith CE, Pittet J-F. Management of the traumatized airway. Anesthesiology. 2016;124(1):199-206.

37. Heidler M-D, Salzwedel A, Jöbges M, Lück O, Dohle $\mathrm{C}$, Seifert $\mathrm{M}$ et al. Decannulation of tracheotomized patients after long-term mechanical ventilation - results of a prospective multicentric study in German neurological early rehabilitation hospitals. BMC Anesthesiol. 2018;18(1):65.

38. Freeman-Sanderson A, Togher L, Phipps P, Elkins $M$. A clinical audit of the management of patients with a tracheostomy in an Australian tertiary hospital intensive care unit: Focus on speechlanguage pathology. Int $\mathrm{J}$ Speech Lang Pathol. 2011;13(6):518-25.
39. Kllıç M, Yüzkat N, Soyalp C, Gülhaş N. Cost analysis on Intensive Care Unit costs based on the length of stay. Turk $\mathrm{J}$ Anaesthesiol Reanim. 2019;47(2):142-5.

40. Reardon PM, Fernando SM, Van Katwyk S, Thavorn K, Kobewka D, Tanuseputro P et al. Characteristics, outcomes, and cost patterns of high-cost patients in the Intensive Care Unit. Crit Care Res Pract [Internet]. 2018 [cited 2020 Jan 27]; 2018(0):1-7. Available from: https://www.ncbi.nlm.nih.gov/pmc/ articles/PMC6139208/ 